\title{
Mystery Case: Tortuous hairs and tortuous blood vessels
}

Indar Kumar Sharawat, MD, Renu Suthar, DM, Sameer Vyas, MD, Amit Rawat, MD, and Naveen Sankhyan, DM

Neurology ${ }^{\circledR}$ 2018;90:e1174-e1176. doi:10.1212/WNL.0000000000005208
Correspondence

Dr. Suthar

drrenusuthar@gmail.com

Figure 1 Clinical features and hair microscopy

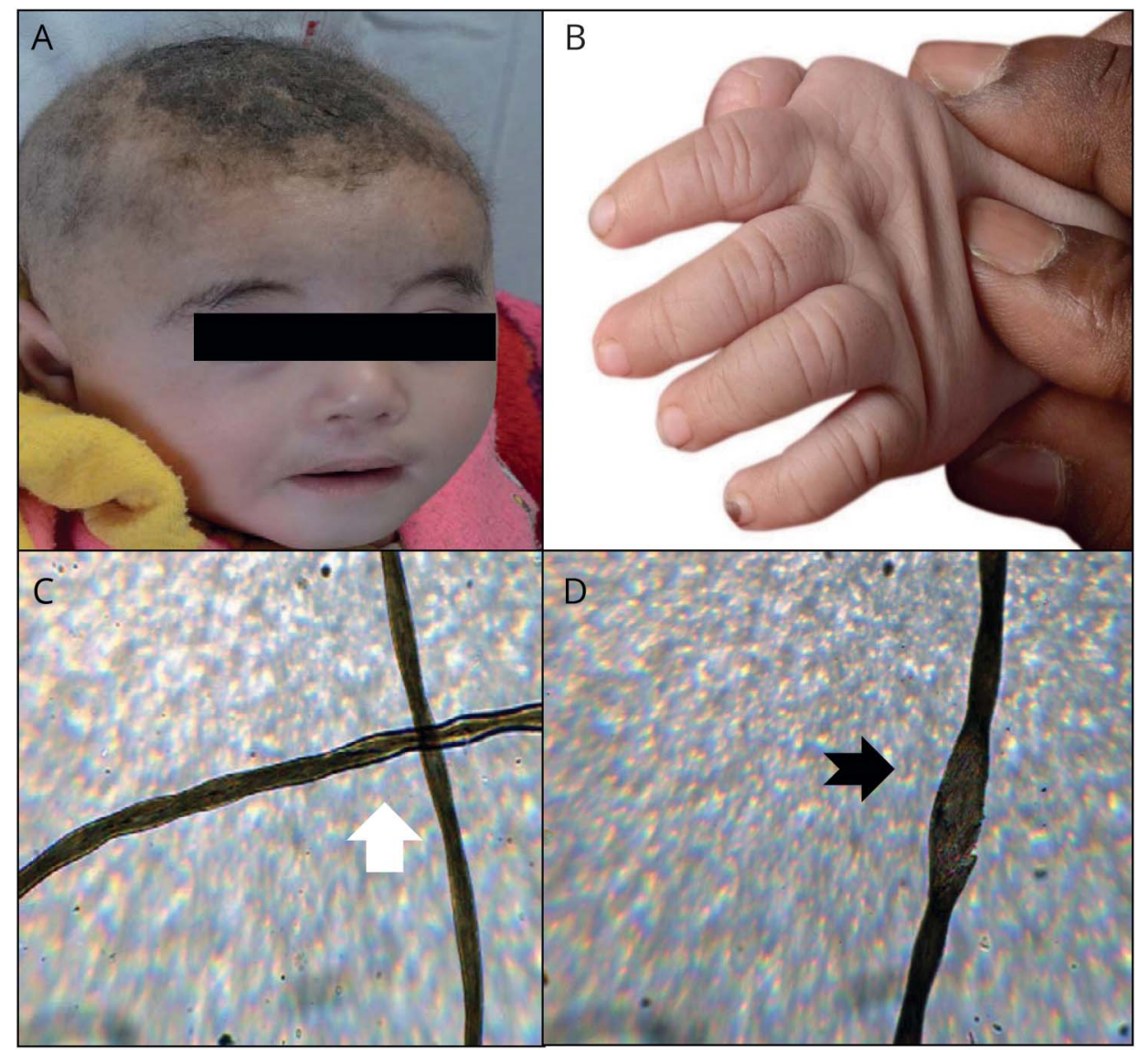

(A) Facial appearance: thin, sparse, short, silvery, wiry hairs and epicanthus. (B) Loose skin folds over dorsum of hand. Hair microscopy: (C) pili torti (180-degree twisting of hair shaft) and (D) trichorrhexis nodosa (formation of nodes along the hair shaft with breakage).
A 5-month-old boy, born to a third-degree consanguineous couple, presented with drugrefractory seizures. On examination, he had microcephaly, abnormal scalp hairs (figure 1A), loose skin folds (figure 1B), and generalized hypotonia. Based on hair microscopy (figure 1, C and $\mathrm{D}$ ), radiologic findings (figure $2, \mathrm{~A}-\mathrm{D}$ ), and a pathogenic mutation in the ATP7A gene (c.4006-1G>C, intron 20), a diagnosis of Menkes disease was confirmed.

\section{Discussion}

Dysfunction of multiple copper-dependent enzymes in Menkes disease, like lysyl oxidase (crosslinks elastin) and sulfhydryl oxidase (crosslinks keratin), results in abnormal vessels, skin, and hair. ${ }^{1}$ Mechanical instability of vessel collagen and remodeling could be mechanisms for the

\section{MORE ONLINE}

Survey and results

NPub.org/MC9013

From the Department of Pediatrics, Advanced Pediatrics Centre (I.K.S., R.S., A.R., N.S.), and Department of Radiodiagnosis and Interventional Radiology (S.V.), Post Graduate Institute of Medical Education \& Research, Chandigarh, India.

Go to Neurology.org for full disclosures. Funding information and disclosures deemed relevant by the authors, if any, are provided at the end of the article. 

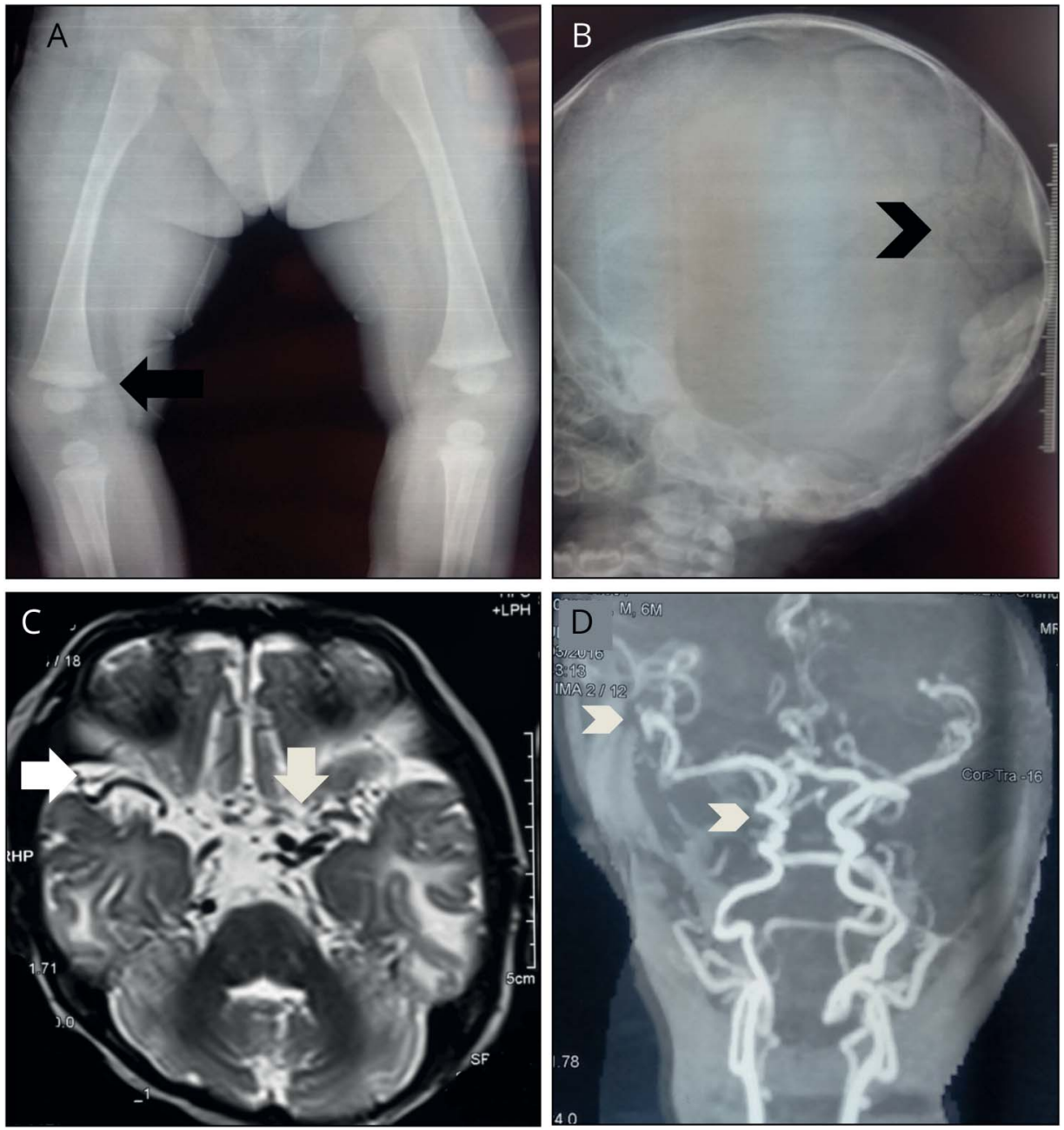

Skeletal X-rays: (A) metaphyseal spurs and (B) wormian bone (intrasutural bones) in the skull. (C) T2-weighted axial MRI section at the level of basal cisterns shows multiple dilated tortuous vessels. (D) Time-of-flight magnetic resonance angiography shows tortuous extracranial and intracranial arteries.

initiation and development of tortuous blood vessels. ${ }^{2}$ Early initiation of copper-histidine therapy may modify disease progression, but prognosis remains poor.

\section{Author contributions}

I.K.S.: patient management, literature review, and initial draft manuscript preparation. R.S.: patient management, critical review of manuscript for important intellectual content, and final approval of the version to be published. S.V.: analysis of the radiologic data and critical review of manuscript. A.R.: analysis of hair microscopy and critical review of the manuscript. N.S.: clinician in charge, concept and design of the report, critical review of manuscript for important intellectual content, and final approval of the version to be published.

\section{Study funding}

No targeted funding reported.

\section{Disclosure}

The authors report no disclosures relevant to the manuscript. Go to Neurology.org for full disclosures.

\section{References}

1. Tümer Z, Møller LB. Menkes disease. Eur J Hum Genet 2010;18:511-518.

2. Han HC. Twisted blood vessels: symptoms, etiology and biomechanical mechanisms. J Vasc Res 2012;49:185-197.

\section{Mystery Case responses}

The Mystery Case series was initiated by the Neurology ${ }^{\circledR}$ Resident \& Fellow Section to develop the clinical reasoning skills of trainees. Residency programs, medical student preceptors, and individuals were invited to use this Mystery Case as an educational tool. Responses were solicited through a group email sent to the American Academy of Neurology Consortium of Neurology Residents and Fellows and through social media. We received 148 responses. The majority of respondents (80\%) had been in practice for 1-4 years; $68 \%$ were residents or fellows, while $20 \%$ were faculty/board-certified physicians. A total of $51 \%$ resided outside the United States. A wide range of practice settings was represented.

First, respondents were presented with a brief summary of the patient's presentation (5-month-old boy born to 
a consanguineous couple, presenting with drug-refractory seizures and hypotonia on examination) and asked to identify the key findings in figure 1, A and B. Microcephaly was correctly identified by $23 \%$ of the respondents, kinky hairs by $60 \%$, loose skin folds by $39 \%$, pili torti (twisted hairs) by $22 \%$, and trichorrhexis nodosa (weak points or nodes causing hair to break off easily) by $9 \%$. The hair abnormality was incorrectly identified as alopecia areata by $29 \%$ of the respondents; this term refers to an autoimmune baldness that may sometimes be associated with neuroimmunologic conditions like myasthenia gravis. ${ }^{1}$

Second, respondents were shown the child's skeletal X-rays and $\mathrm{MRI} /$ magnetic resonance angiography brain (figure 2, A-D), and asked to identify the key findings. Tortuous intracranial arteries were correctly identified by $55 \%$ of the respondents, and tortuous extracranial arteries by $28 \%$. The more subtle finding of metaphyseal spurs was correctly identified by $21 \%$, and wormian bone (extra bone within cranial sutures) by $17 \%$. A total of $22 \%$ incorrectly identified the patient's bone abnormality as fibrous dysplasia; this involves replacement of normal bone with large fibrous stroma and islands of immature woven bone and can be seen in disorders like McCune-Albright syndrome (with precocious puberty and café-au-lait spots). ${ }^{2}$
Finally, when asked to identify the most likely diagnosis (and associated gene) for the patient on the basis of these findings, $72 \%$ of the respondents correctly identified this as a case of Menkes disease with ATP7A mutation. The most frequent alternative choice was mucopolysaccharidosis IIIA (5\%), a severe early childhood neurologic condition caused by autosomal recessive SGSH mutations. In addition to developmental delay and behavioral problems, these patients can also have seizures as well as hair and skeletal abnormalities, with coarse hair texture, stiff joints, and dense calvaria. Tortuous vessels are not usually described in mucopolysaccharidosis IIIA. ${ }^{3}$

This Mystery Case provides a succinct overview of key clinical and radiologic findings in Menkes disease.

\section{Aravind Ganesh, MD}

Department of Clinical Neurosciences, University of Calgary, Canada; Nuffield Department of Clinical Neurosciences, University of Oxford, UK.

\section{References}

1. Kubota A, Komiyama A, Hasegawa O. Myasthenia gravis and alopecia areata. Neurology 1997;48:774-775.

2. Collins MT, Singer FR, Eugster E. McCune-Albright syndrome and the extraskeletal manifestations of fibrous dysplasia. Orphanet J Rare Dis 2012;7 (suppl 1):S4

3. Nijmeijer SCM, Wijburg FA. Mucopolysaccharidosis type III: current clinical trials, challenges, and recommendations. Expert Opin Orphan Drugs 2018;6:9-15. 


\title{
Neurology
}

\author{
Mystery Case: Tortuous hairs and tortuous blood vessels \\ Indar Kumar Sharawat, Renu Suthar, Sameer Vyas, et al. \\ Neurology 2018;90;e1174-e1176 \\ DOI 10.1212/WNL.0000000000005208
}

This information is current as of March 26, 2018

Updated Information \&
Services

References

Subspecialty Collections

Permissions \& Licensing

Reprints including high resolution figures, can be found at: http://n.neurology.org/content/90/13/e1174.full

This article cites 5 articles, 1 of which you can access for free at: http://n.neurology.org/content/90/13/e1174.full\#ref-list-1

This article, along with others on similar topics, appears in the following collection(s):

Developmental disorders

http://n.neurology.org/cgi/collection/developmental_disorders MRI

http://n.neurology.org/cgi/collection/mri

Information about reproducing this article in parts (figures,tables) or in its entirety can be found online at:

http://www.neurology.org/about/about_the_journal\#permissions

Information about ordering reprints can be found online:

http://n.neurology.org/subscribers/advertise

Neurology ${ }^{\circledR}$ is the official journal of the American Academy of Neurology. Published continuously since 1951, it is now a weekly with 48 issues per year. Copyright @ 2018 American Academy of Neurology. All rights reserved. Print ISSN: 0028-3878. Online ISSN: 1526-632X.

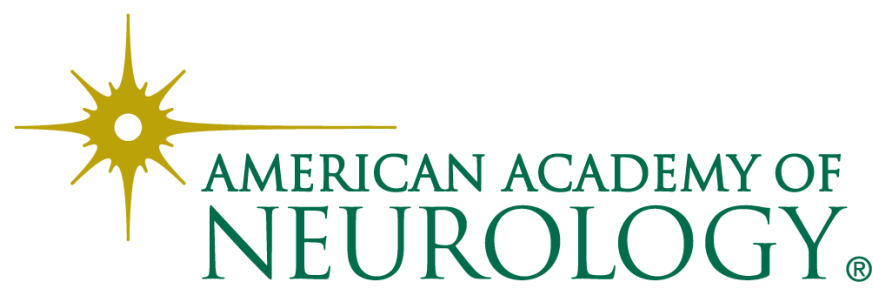

